\title{
Correr e competir: a corrida de rua como uma prática corporal vivida por mulheres.
}

\author{
Helena Altmann (PQ), Giovanna G. Ticianelli (IC).
}

\section{Resumo}

As corridas de rua cresceram no Brasil nos últimos anos, tanto no que se refere ao número de competições, quanto ao número de participantes, sendo tal crescimento mais significativo entre as mulheres. A presente pesquisa teve como objetivo analisar a experiência com as corridas de rua de mulheres que participam de competições, no que diz respeito ao espaço dessa prática na vida das praticantes, a relevância, os objetivos, a relação da corrida com o corpo. Também foi analisada a influência das competições na aderência à prática, como são sistematizados os treinos, qual a importância das competições e quais benefícios são percebidos através da prática dessa modalidade. Para isso foram feitas entrevistas semiestruturadas com dez corredoras amadoras, que já praticam a modalidade há pelo menos um ano e participaram de pelo menos dois eventos de corrida de rua. Foi percebido que as corredoras iniciaram a prática da corrida com o objetivo de emagrecer, mas conforme aderiram a prática os objetivos passaram a ser direcionados a corrida propriamente dita, como aumentar as distâncias percorridas e a velocidade de corrida. Para isso, assim como os treinos feitos de maneira sistematizada as competições ajudam na motivação e criação de novos objetivos. As mulheres corredoras utilizam-se da corrida como um momento de agrado a si mesmas, em que podem estar sozinhas, sentindo-se importantes e gerando um sentimento de superação. É uma fuga da rotina que as ajuda a pensar, relaxar e que gerou um novo estilo de vida para elas e para as pessoas que as cercam.

Palavras Chave:corrida de rua, mulheres, gênero.

\section{Introdução}

O número de mulheres corredoras vem aumentando no Brasil, na São Silvestre, por exemplo, uma das corridas mais conhecidas no mundo, realizada na cidade de São Paulo todos os anos no dia 31 de dezembro, em 2013 havia 2.446 corredoras inscritas a mais do que em 2008, representando assim uma crescente inserção das mulheres nesse esporte.

Qual o objetivo das mulheres praticantes amadoras com a corrida? Por que e com quais expectativas elas começaram e continuam praticando a modalidade? Como as competições se relacionam com a prática da corrida? Como a corrida esta inserida no dia-a-dia dessas praticantes? Qual o significado da corrida para elas? Esses são os questionamentos que pretendemos responder com a presente pesquisa e, para isso, foram feitas entrevistas com mulheres corredoras amadoras da cidade de Bauru.

\section{Resultados e Discussão}

A partir das entrevistas foi percebido que o início na corrida esta relacionado ao emagrecimento, porém a partir da prática contínua os objetivos relacionam-se à modalidade propriamente dita, como aumento das distâncias e da velocidade. As competições foram apontadas como um fator de motivação para a prática e para alcançar os objetivos propostos. Os treinos são realizados com seriedade e estão presentes de maneira organizada na rotina das praticantes. A corrida tornou-se um momento de relaxamento e de agrado a si própria para essas mulheres, assim como um estilo de vida.

\section{Conclusões}

Conclui-se que as mulheres corredoras amadoras entrevistadas possuem a corrida como um estilo de vida. A corrida é um momento em que essas mulheres estão felizes e agradando a si mesmas, podendo traçar os seus objetivos, treinar $\mathrm{e}$ organizar o seu dia-a-dia para que consigam alcançar o almejado. A prática é um importante momento em que essas mulheres passam a ser exemplos para as pessoas que as cercam. Fazendo com que elas sintam-se realizadas por serem protagonistas dos seus resultados.

\section{Agradecimentos}

A pesquisa teve financiamento do CNPq, através do Programa de Bolsas de Iniciação Científica (PIBIC).

SCOTT, Joan. Gênero: uma categoria útil de análise histórica. Educação e Realidade, Porto Alegre, v. 20, n. 2, p. 71-99, jul./dez., 1995. 